\title{
A Review of Climate-Smart Agriculture Technology Adoption by Farming Households in Sub-Saharan Africa
}

\author{
Richard Kombat ${ }^{1,2, *(D)}$, Paolo Sarfatti ${ }^{1}$ and Oluwole Abiodun Fatunbi ${ }^{1}$ (D) \\ 1 Forum for Agricultural Research in Africa, No. 9 Flower Avenue New Achimota Mile 7, \\ Accra PMB CT 173, Ghana; psarfatti@icloud.com (P.S.); ofatunbi@faraafrica.org (O.A.F.) \\ 2 Faculty of Agriculture, University for Development Studies, Tamale P.O. Box TL 1882, Ghana \\ * Correspondence: rkombat@faraafrica.org; Tel.: +233-203-835775
}

\section{check for}

updates

Citation: Kombat, R.; Sarfatti, P.; Fatunbi, O.A. A Review of Climate-Smart Agriculture Technology Adoption by Farming Households in Sub-Saharan Africa. Sustainability 2021, 13, 12130. https: / / doi.org/10.3390/ su132112130

\section{Academic Editors:}

Roberto Mancinelli and

Michael S. Carolan

Received: 31 August 2021

Accepted: 18 October 2021

Published: 3 November 2021

Publisher's Note: MDPI stays neutral with regard to jurisdictional claims in published maps and institutional affiliations.

Copyright: (c) 2021 by the authors. Licensee MDPI, Basel, Switzerland. This article is an open access article distributed under the terms and conditions of the Creative Commons Attribution (CC BY) license (https:/ / creativecommons.org/licenses/by/ $4.0 /)$.

\begin{abstract}
Climate change is a major constraint to the progress of Africa's agriculture, food, and nutrition security; its effect is tied to geographical position and driven by the limited adaptive capacity of the agricultural households. The most vulnerable stakeholder group are the smallholder farming households with limited resources and knowledge of adaptation and mitigation techniques. Sub-Saharan Africa owns more than $60 \%$ of the world's arable land with over $85 \%$ of the farmers being smallholder farmers, who are predisposed to various risks. This paper analyzes the adoption of climate-smart agriculture (CSA) processes and technologies by smallholder farming households in Sub-Saharan Africa. The study used mixed methods and an integrative literature review. This review indicated that the knowledge of CSA technologies by smallholder farmers in Africa is increasing and, thus, concerted efforts to continuously generate CSA technology would contribute to the desired positive outcome. To accelerate the pace of adoption and use of the technologies, the linkage of farmers, researchers, and extension practitioners is needed. Measures should also be put in place to ensure that CSA actions are implemented using bottom-up approaches.
\end{abstract}

Keywords: smallholder farming household; climate-smart agriculture; technologies; adaptation; food security; Sub-Saharan Africa; biennial climate-smart agricultural stakeholders conference; SDGs

\section{Introduction}

Across the globe, climate change is rapidly affecting every aspect of life, and the agricultural system is the most affected [1]. There has been a steady yet significant increase in temperature (both maximum and minimum) trends across the Sub-Saharan African (SSA) region. There is also a rise in sea levels, and heavy rains, hailstorms, and droughts have occurred in different locations within SSA in the past decade [2]. This has adversely affected the agricultural sector, it has shifted the farming trends and patterns, and caused the number of emigrants from the Sub-Saharan Africa countries to grow by $50 \%$ or more over the years 2010 and 2017 [3]. Food and nutrition security of the farming households has been affected, leaving about $39 \%$ of households in a state of food insecurity and as many as $49 \%$ of the households with different levels of micronutrient deficiency [4]. This suggests that the United Nations (UN) Sustainable Development Goals (SDGs) one and two (no poverty and zero hunger) may not be actualized on the continent, despite the efforts at different levels to end poverty and increase food and nutritional security globally.

Climate change is greatly shifting the way agricultural activities are being conducted. In every region of SSA, plants, animals, and ecosystems are adapting to the new, unbalanced climatic conditions. The danger of climate is such that when the conditions change slightly, even in a direction that may seem more favorable to humans, the growth of plants and livestock tends to be affected; some will go extinct, and others will become less productive. Some of these shocks can be easily predicted, such as the direct impact of a heatwave on plants at an early stage of growth [5]. The effect of certain changes in climatic conditions may be difficult to predict, such changes could affect the entire ecosystem and its functions. 
The response of the ecosystem to changes is complex to decipher because each element in the system will respond independently and interact with other elements differently. For instance, many cultivated plants react favorably, in controlled conditions, to an increase of $\mathrm{CO}_{2}$ in the atmosphere. However, at the same time, many weeds also react favorably to the same treatment [5]. The result in the field can be an increase or decrease in the yield of the cultivated plants, depending on the level of competition for nutrients and water by the weeds as well as on the kind of agronomic practices.

About $80 \%$ of farmers in SSA are smallholders [6]; they are largely vulnerable to the vagaries of the changing climate. They are poorly resourced and lack adequate knowledge of the phenomenon, hence there is a need to develop their capacity to appreciate and use the available adaptation and mitigation techniques. Since the emergence of climate change, measures have been put in place by the governments and organizations to check the progression of climate change and reorient the agricultural systems to effectively support agricultural development and ensure food security [5].

In addition to climate change, other global forces, or megatrends, are currently underway, with the potential to exacerbate the challenges that African countries are facing in transforming their economies. These megatrends include demographic changes, especially the upsurge in the population of the youth, growth in the middle class, increased urbanization, rapid technological changes, and the associated increase in anti-social behaviors. The supply of products from natural resources, such as food, water, energy, and ecosystems services, continues to receive pressure as demographic trends are projected to yield an increase in Africa's population by the year 2050 [7]. Concepts such as climate-smart agriculture could be used to help smallholder farmers adapt to climate change and, at the same time, mitigate greenhouse gas (GHG) emissions.

Climate-smart agriculture (CSA) technologies have been developed by scientists and researchers amidst the high rise in climate change [8]. Some of these technologies are improved versions of old practices while a few others are entirely new in the system. Appropriate technologies to adapt to the changing climatic condition will necessarily need to be drought-tolerant, grow and produce well within a short duration, tolerant to multiple pests and diseases, able to produce well under marginal soil fertility conditions, and high yielding among other desirable traits. These technological traits embedded in the seeds are vital and should be supported by appropriate agronomic practices to aid the climate change mitigation process. Mitigation efforts tend to be broad and exist at higher levels of governance and management of the ecosystem. Practices that reduce carbon emission, such as limiting the use of fossil fuels, reducing bush burning, etc., will require long-term advocacy for behavioral change among the populations within the regions in SSA. In this paper, we analyzed and discussed the current levels of adoption of CSA technologies and practices by smallholder farming households in SSA. We employ both qualitative and quantitative analysis methods to measure and determine the level of CSA technology adoption, the options, and the future projection of the agriculture system in terms of climate change.

\section{The Role of Climate-Smart Agriculture}

The earlier definition of CSA by [9] stated that "Climate-smart agriculture (CSA) is an approach that helps to guide actions needed to transform and reorient agricultural systems to effectively support the development and ensure food security in a changing climate." This came at a time when there was considerable controversy around the concept and approaches to sustainable agricultural development. These earlier definitions have been refined by other authors who largely integrate terms, such as mitigation, adaptation, and management to foster a more coherent understanding of the concept. CSA is an integrative approach that addresses the interlinked challenges of food security, variability in climate, and other systemic issues such as demography, that support agricultural production. The three central objectives of CSA include: (a) sustainably increasing agricultural productivity, to support equitable increases in farm incomes, food security, and development; (b) adapt- 
ing to and building the resilience of agricultural and food security systems to climate change at multiple levels; and (c) reducing greenhouse gas emissions from agriculture (including crops, livestock, and fisheries) [10].

However, the most popularly used definition of CSA is the definition given by [11,12], which focuses on key elements regarding the relationship between CSA, livelihoods, productivity, and ecosystems function. It highlights the need to reduce GHG emissions and achieve national food security. Thus, it is noted that the definition of CSA is based on its purpose, audience, project type, institutional framework, and individual interest. Recent observations suggest that the increase in population and its associated activities is contributing to climate change and its effects. Currently, there are no known definitions of CSA that include demography. Therefore, incorporating demography into the definitions of CSA will foster the required attention to demographic management in SSA. In general, CSA will be the only way to design holistic mitigation and adaptation options for the changing climate. Agricultural production would increase, and more technologies would be developed and employed in the sector, as manual labor will dwindle significantly.

\section{Materials and Methods}

This study was carried out using the mixed-method research approach, and an integrative literature-review method, as described by [13]. The analysis addressed the research papers which were published following the Biennial Climate-Smart Stakeholders Conference, which was held on 1st and 2nd December 2020, and the changes in African agriculture. The research methods require systematic integration of qualitative and quantitative data and analysis within a single investigation [14]. Historical overview, research articles, books, and other publications $[13,15]$ were considered. These approaches aimed to combine various fields of research and the different views from the various publications that emanated from the conference and link them to the current happenings in Africa.

The study concentrated on the Sub-Saharan Africa (SSA) region. It has a land size of about 24 million $\mathrm{km}^{2}$ [16] and represents $79 \%$ of the total land area of Africa and about $18 \%$ of the world land area. The SSA lies south of the Sahara and consists of 46 African countries [17] and territories that are fully or partially south of the Sahara. The region is affected by serious environmental problems, including deforestation, soil erosion, desertification, wetlands degradation, and insect infestations. The majority of these environmental problems are further exacerbated by changes in the climate.

Most of SSA has a tropical climate; $70 \%$ of the continent lies between the tropic of Cancer (northern tropic) and the tropic of Capricorn (southern tropic), as shown in Figure 1. The region has eight well-defined terrestrial biomes with well-defined agroecological notations and production capacities (Figure 2).

The largest biome is tropical and subtropical savannahs and grasslands: a mosaic of grasslands, woodlands, bushlands, thickets, and semi-arid drylands that are maintained by fire and grazing. East and southern Africa's miombo and mopane savannah-woodland are included in these ecosystems.

Efforts to deal with the problems of climate change are handicapped by the failure to understand the nature of the problem and possible remedies. 


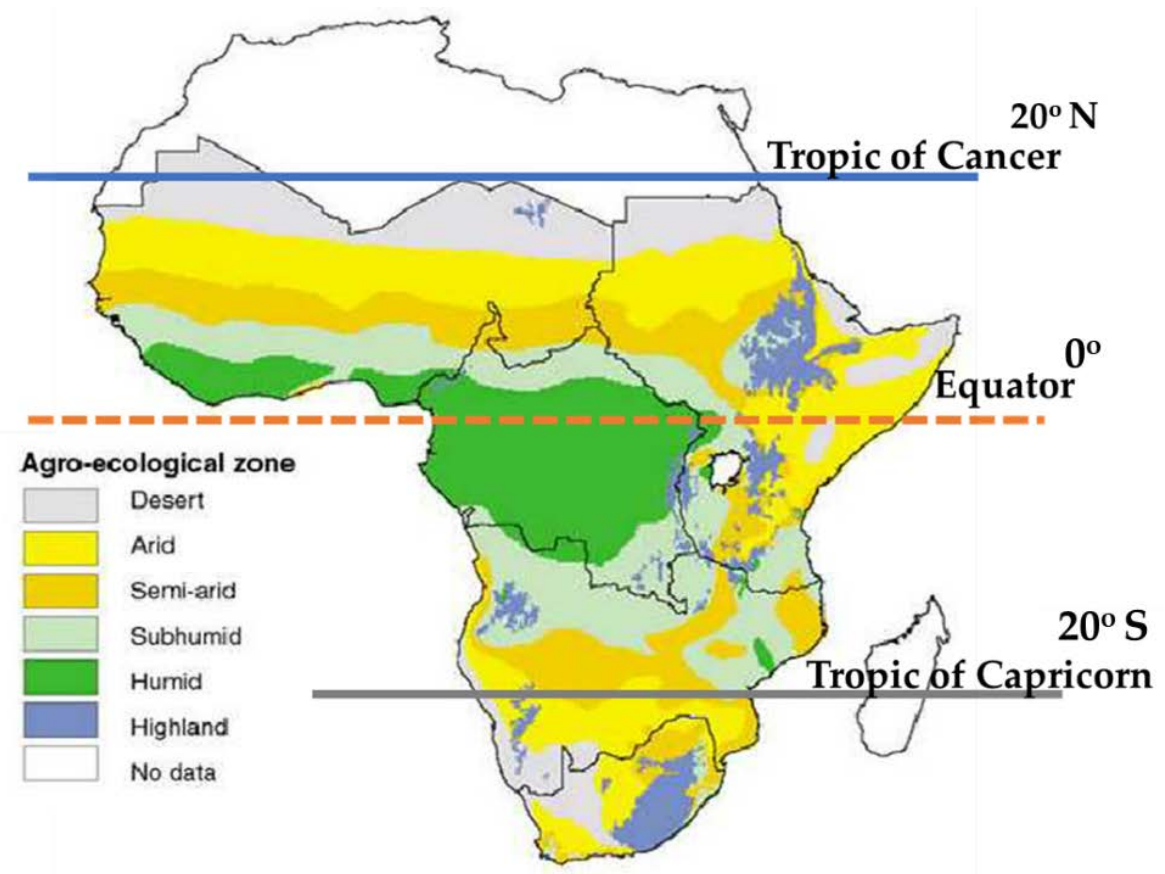

Figure 1. Agro-ecological zones of SSA and Africa position on the tropics of cancer and Capricorn. Source: adapted from [18].

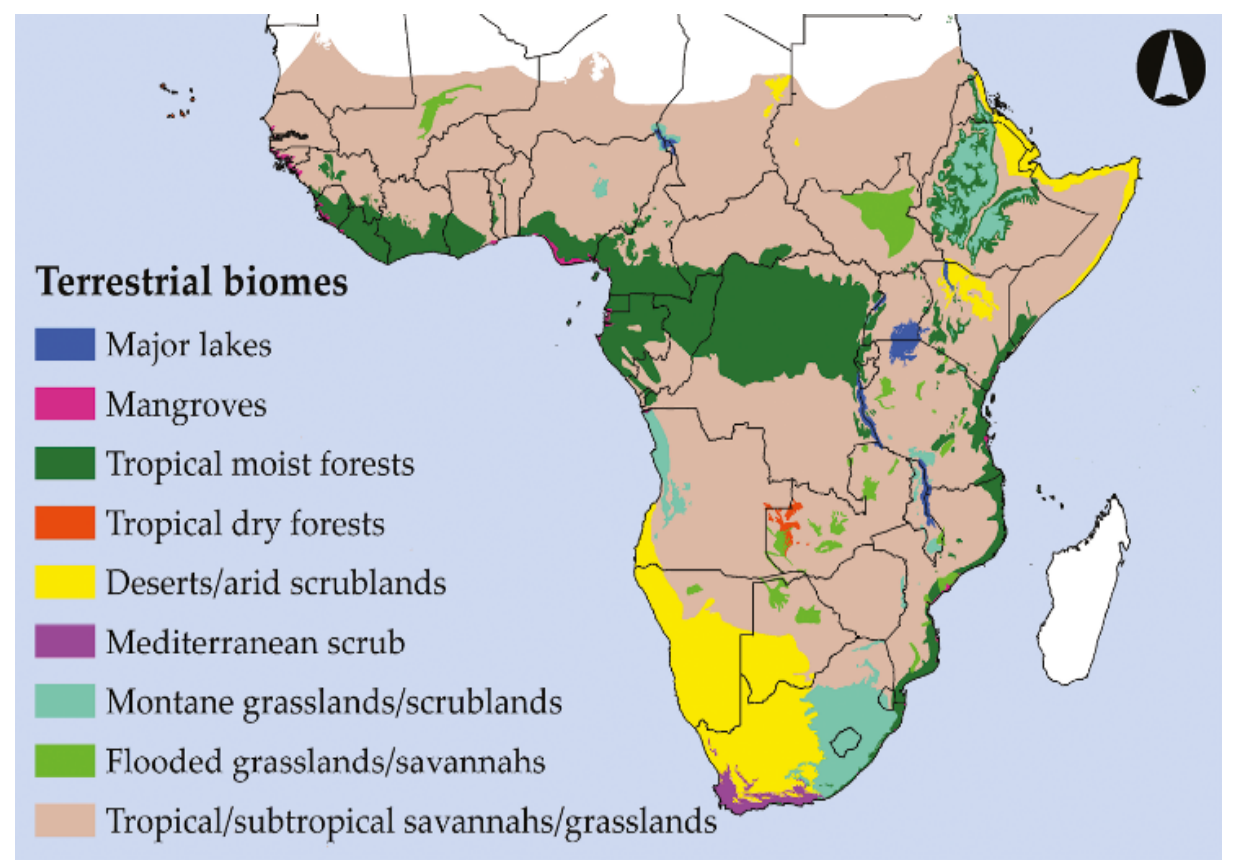

Figure 2. Map of Sub-Saharan Africa's eight terrestrial biomes. The region's topographic complexity, the diversity of biomes, and the multiple ecological transition zones between the different biomes have given rise to rich biodiversity. Source: [19].

In Table 1, which is shown below, we selected the published papers, following the FARA CSA stakeholders conference which was held on December 1st and 2nd 2020, and some articles, research papers, works, and books that address CSA technologies and CSA utilizations focusing on Sub-Saharan Africa and adaptations of CSA in SSA. The policy brief generated from the conference was considered, as it addressed most of the major issues from the conference. 
Table 1. List of documents consulted.

\begin{tabular}{|c|c|c|}
\hline Author and Year & Contribution & Geographical Location/Region \\
\hline $\begin{array}{l}\text { Girvetz. et al., } 2019 \\
\text { [20] }\end{array}$ & Climate-Smart Foresight & Eastern and Southern Africa \\
\hline $\begin{array}{c}\text { Zougmore et al., } 2021 \\
{[21]}\end{array}$ & Food System Transformation & Sub-Saharan Africa \\
\hline $\begin{array}{c}\text { Osumba et al., } 2021 \\
\text { [22] }\end{array}$ & Extension Service Delivery & South Africa \\
\hline $\begin{array}{c}\text { Ajuruchuku and Okuhle, } 2021 \\
\text { [23] }\end{array}$ & Innovative CSA practices & South Africa \\
\hline $\begin{array}{l}\text { Beattie and Sallu, } 2021 \\
\text { [24] }\end{array}$ & CSA Policy & Burkina Faso, Senegal and Sierra Leone \\
\hline $\begin{array}{l}\text { Shimelis and Rainer, } 2021 \\
\text { [25] }\end{array}$ & Seed Innovation & Ethiopia \\
\hline $\begin{array}{l}\text { Titay et al., } 2021 \\
{[26]}\end{array}$ & Smallholder Farmers Vulnerability & Sub-Saharan Africa (Ethiopia) \\
\hline $\begin{array}{c}\text { Ofoegbu, et al., } 2019 \\
\text { [27] }\end{array}$ & Climate Change Adaptation Strategies & South Africa \\
\hline $\begin{array}{c}\text { http: / / www.climatelinks.org } \\
12 \text { August } 2021 \\
\text { [28] }\end{array}$ & Adaptation & Africa \\
\hline $\begin{array}{c}\text { Biennial Climate-Smart Agriculture } \\
\text { Stakeholders Conference-Policy Brief } \\
\text { FARA } 2020 \\
{[29]}\end{array}$ & Policy Brief & Africa \\
\hline $\begin{array}{l}\text { Onoja et al., } 2019 \\
\text { [30] }\end{array}$ & CSA Practices and Adaptation & West and East Africa \\
\hline $\begin{array}{c}\text { Kurgat et al., } 2020 \\
{[31]}\end{array}$ & CSA Technology Adaptation & Tanzania \\
\hline $\begin{array}{l}\text { Partey et al., } 2018 \\
\text { [8] }\end{array}$ & CSA Challenges and Lessons Learnt & West Africa \\
\hline $\begin{array}{c}\text { Bell et al., } 2018 \\
\text { [32] }\end{array}$ & CSA Technologies Guide & Africa \\
\hline $\begin{array}{c}\text { Barasa et al., } 2021 \\
\text { [33] }\end{array}$ & CSA Application & Africa \\
\hline
\end{tabular}

The review identified some innovative CSA practices in the smallholder farming systems; it highlighted the importance of the extension system in delivering knowledge and technologies to the smallholder farmers and the need for an effective policy system to ensure the delivery of CSA gains in SSA. To identify prominent CSA technologies, and assess their utilization, a major search engine like Google search, Google Scholar, and various developmental organization websites viz., FAO, World Bank, and IFAD web pages were (accessed on $30 \mathrm{July}, 2021$ ). Emphasis was given to the papers presented and published by authors that participated in the Biennial CSA conference. Six high-quality publications from the conference and nine other reports of original research work on CSA technology generation, adoption, and utilization were selected and reviewed. The contributions of each study to the analysis of CSA technology adoption by smallholder farmers in SSA were assessed. 


\section{Results and Discussion}

\subsection{Review of CSA in Africa: Core Issues and Constraints in Agriculture}

Since the early 1970s, climate change and its adverse effects have become a reality in Africa [20], resulting in new and diversified phenomena, including, among other things, an increase in temperature, low agricultural production, intense alterations in weather patterns, and disease transmission. Research has shown that Africa's carbon $\left(\mathrm{CO}_{2}\right)$ emissions are practically lower than the rest of the world, yet the continent is the most vulnerable to the effects of climate change [34]. Africa's vulnerability to climate change is attached to a chain of factors, including weak adaptive capacity, high reliance on ecosystem goods for livelihoods, and traditional agricultural systems [27]. The impacts of climate change posed a significant challenge to global food and nutrition security, and this is projected to worsen over the coming years due to livelihood pressures, such as a rise in population, economic development, urbanization, and the frequent occurrences of natural hazards, such as extreme temperatures, droughts, and floods, among others [33]. The vulnerability to the constraints from climate change will be further exacerbated by the growing food demand from the increasingly rich population in SSA, and the reduction of the rural population due to huge migrations to the urban cities in search of white-collar jobs [35].

Using general circulation models (GCMs) and the Representative Concentration Pathway 2.6 (RCP2.6), [17] to make a future prediction; it was deduced that the ambient temperature may increase by $1.5^{\circ} \mathrm{C}$ by the year 2050; this is far above the $1951-1980$ baseline, and shall remain till the end of the century. There is a likelihood of an increase in temperature, droughts, and floods in the coming years [35]. Some regions in Africa are also expected to experience an increase in night temperature in the future, as well as longer and more frequent heatwaves. The projections further showed that some locations within the SSA region will experience strong drying, with a significant increase in the length of dry spells.

In Sub-Saharan Africa, climate change is currently not at its peak; past variations in temperature and precipitation have shown immediate implications for food production and security across the continent [36]. Drought, heat stress, and flooding have exacerbated the already low production of crops, livestock, and aquatic species, and have contributed to the increased rates of malnutrition and poverty, leading to a reduced quality of life and health $[5,37]$. Food shortages are a known cause of cross-border migration [38], and this is estimated to worsen by the year 2050. The prevalence of hunger and poverty will be highest in SSA in comparison to other locations on the continent, making it substantially hard to access food due to the huge increase in the population [39].

Climate suitability for most crops, animals, and aquatic life is expected to deviate from normal as the climate becomes warm [40]. For instance, West Africa (WA) has been identified as a climate-change hotspot [41], and climate change will lead to a high reduction in crop yields, thus increasing food insecurity in the region [42-44]. Climate change in SSA is tied to geographical position and limited adaptive capacity [45], and it is worsened by widespread poverty and low levels of development. Another effect of climate change is the outbreak of diseases, pests, and internal conflicts driven by the depletion of essential resources, such as potable water or vegetation for grazing, etc.

Given these, there is the need to practice and adopt CSA technologies and other practices in SSA. The CSA technological options targeting increased agricultural production could be adopted, tested, and modified to suit the continent. This knowledge and these technologies include advanced plant breeding, genomics, phenomics, advances in plant phenotyping, the use of robots, and artificial intelligence tools [46,47]. The availability of computer resources on plants and animals' genomics, modeling, and improved applications of synthetic biology [48], are providing insights into the complex biological mechanisms which underlie plants' responses to stresses, resulting from climate change. These resources simultaneously provide opportunities to expand the range of how possible plants products can be best adopted. 
Therefore, Africa must make use of these available CSA technologies (e.g., tools, equipment, methods, and processes, etc.). This will increase the speed at which most agri-food stakeholders adapt to CSA in preparation for the future effects of climate change. Additionally, attention should be drawn to breeding programs focused on breeding crops for high yields and superior adaptability to new and evolving climate scenarios, to ensure sustained food security, biomass production, and ecosystem services in SSA [47].

\subsection{The Role of CSA Technology Options, Utilization, and Adaptation}

CSA technology options integrate traditional and innovative practices, technologies, and services that are important for a particular location to adapt to climate change and variability $[49,50]$. This involves the use of not only Information and Communication Technologies (ICT) based tools but also plants and animal breeding methods, the use of modern and local greenhouses for crop cultivation, irrigation methods, and innovative livestock production systems. These include the traditional water harvesting systems on the fields, building ridges to store water, fish farming in rice fields [51], and mixed farming and cropping methods. Ideally, innovations, practices, or technologies should address and achieve all the CSA pillars (productivity, resilience, and GHG emission).

Generally, for the CSA technologies options to be effective, researchers and CSA developers should work hand in hand with farmers to develop and make sure these technologies are suitable for the farmers and their environment. Hence, decisions should consider climatic risks, making short and long-term adjustments to the developed technologies, depending on the extent of the current climate variability and expected climate change in the future, which must be carefully monitored. The users of these CSA technologies are the small household farmers who do not have the control, technical knowledge, and ownership of these technologies. Therefore, it is important to involve them in the development of these technologies to ensure the demand, their sense of ownership, and for them to have a good and practical knowledge of the technologies.

Figure 3 shows the awareness and use of CSA technologies in Eastern Africa on intercropping, seed selection, improved varieties, agroforestry, and minimum tillage.

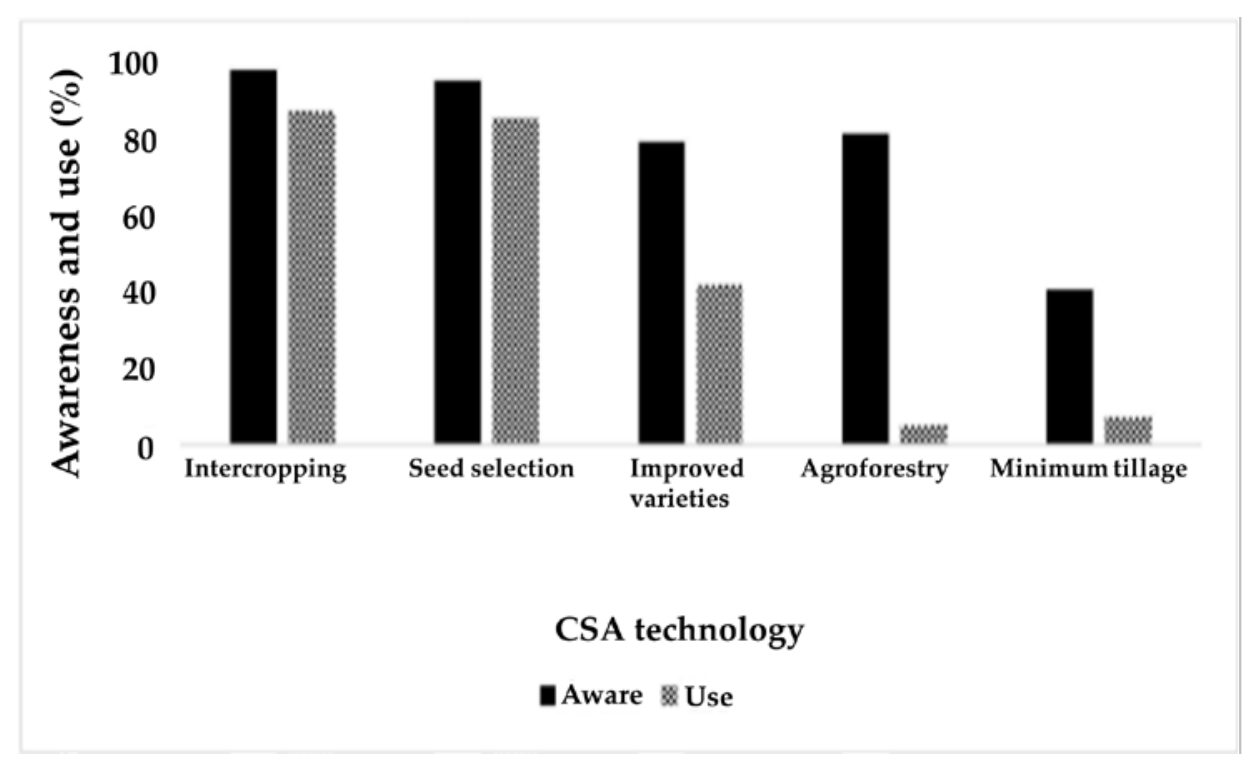

Figure 3. CSA technology awareness and use in some locations in Eastern Africa. Source: FARA, 2015A [52].

The above are among the most common groupings of CSA technologies available in SSA. The level of use and awareness in (\%) was determined from the selection of over 10,000 farmers each from Ethiopia, Kenya, and Uganda in 2014-2015, to ascertain the levels of the commonly available CSA technologies in the continent. However, it was noted that 
the majority of the smallholder farmers were aware of these technologies but did not know that they were climate-smart technologies, rather, they thought of them as a form of the farming system practices, especially with regard to intercropping. Most of the smallholder farmers said intercropping to them is only a smart revenue generation since they can cultivate more than one type of crop commodity from the same piece of land using the same amount of energy and time. Hence the high use of this technology (85\%). In addition, $90 \%$ of the farmers said that seed selections are a smart way of getting the best cultivar for planting and that they did not know that this is a CSA technology. It was then noted that CSA technology awareness in East Africa is high and that its use was increasing. The farmers, however, knew little or nothing about the term "CSA technologies", even in the cases where they use climate-smart technologies.

However, in Figure 4, as shown below, the use of CSA technologies was low because smallholders complained that it was expensive to practice these technologies, but they still had a piece of high knowledge about the technologies. Some of the farmers said that these technologies are indigenous since they grew up seeing their fathers and grandfathers practicing these types of farming. It was, however, difficult to persuade them that these were climate-smart farming methods and not just indigenous farming.

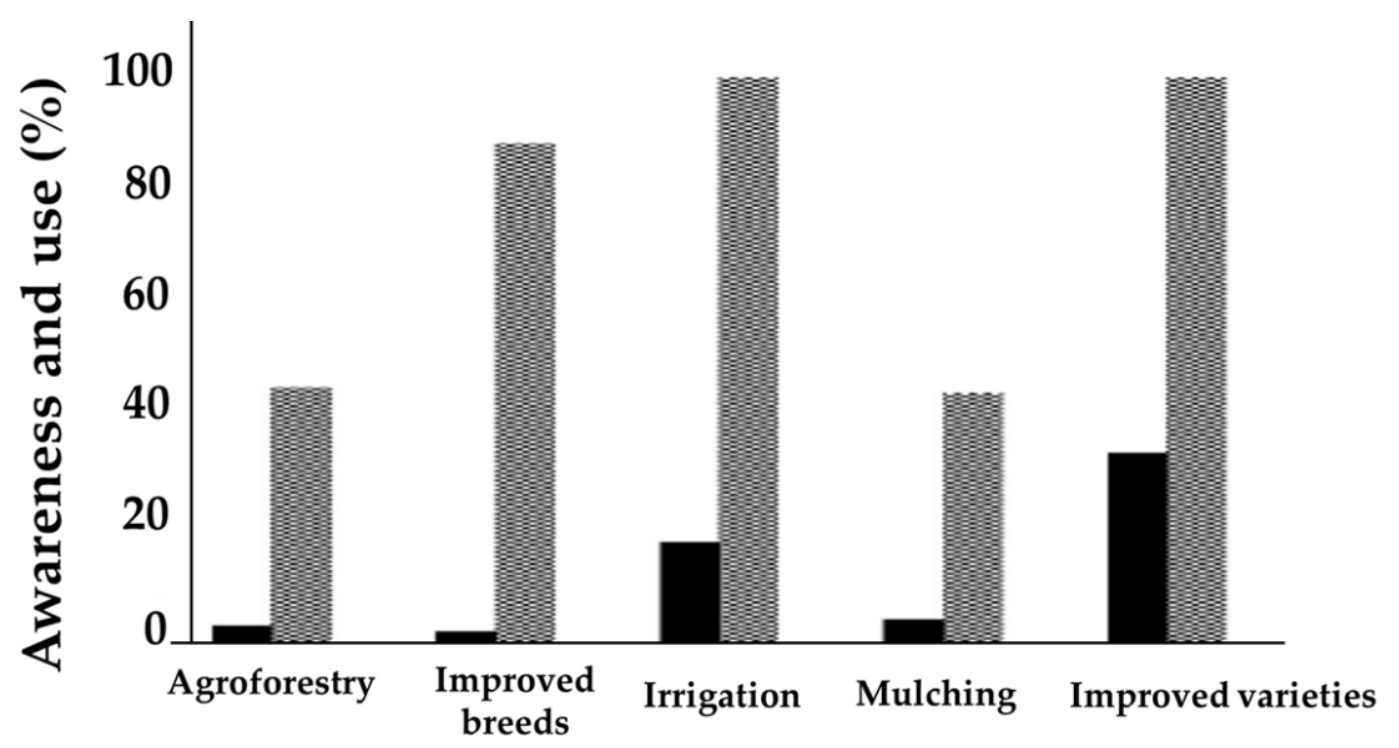

\section{CSA technology}

-Aware Use

Figure 4. CSA technology awareness and use in some locations in Western Africa. Source: FARA, 2015B [53].

\subsection{Sub-Sahara Africa Population Distribution in Rural and Urban Cities}

SSA is known to have a population largely involved in agriculture as its main source of income and livelihoods, and hence a majority of the population (59\%) lives in the rural areas/farming communities of the region. Figure 5 below shows the trend in the growth of urbanization for the past 10 years. 


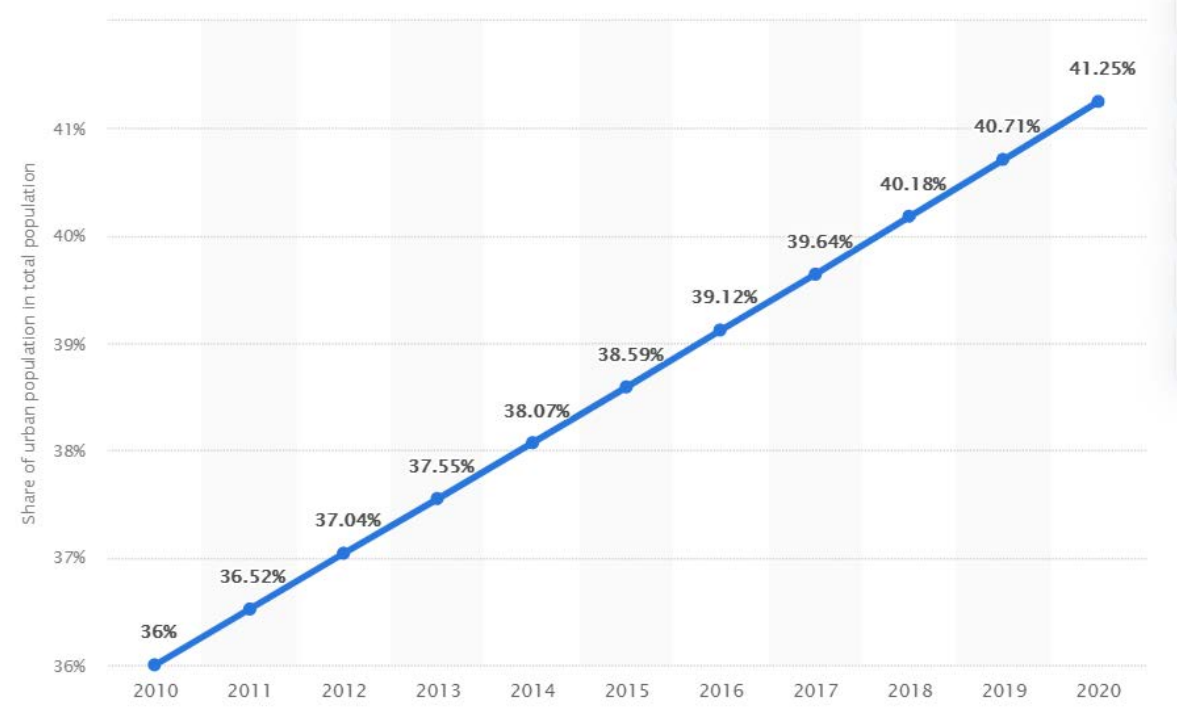

Figure 5. SSA Urbanization from 2010 to 2020 Source: [54].

It can be seen from Figure 5 above that urbanization in SSA is increasing steadily and this has affected food security in the region. As more people migrate to the cities, fewer people are engaged in farming activities in the rural area of SSA, resulting in a decline in food production and supply. This is further exacerbated by the change in climatic conditions. The population increase in the region is a major contributor to deforestation and climate change in Sub-Saharan Africa in different ways. Forests are being destroyed for buildings and energy production, and factories are being built in urban areas, which attracts rural-to-urban migration. Similarly, urban transportation is on the rise, as more people migrate into the urban areas, causing more $\mathrm{CO}_{2}$ to be released into the atmosphere $[55,56]$. Conversely, smallholder low-production agriculture plays an important role in forests being maintained, as they ensure food security [57].

\subsection{Farmer Households and Demographic Change}

As it is projected that the population in SSA is going to double by the year 2050, there is the likelihood of an increase in food demand and an increase in urbanization [11]. Africa is largely dependent on smallholder farmers for the majority of its food, and an increase in population means less food and increased food insecurity in the continent.

In the literature, the term "farming household" is often used interchangeably with that of "smallholder farms". In this context, references to size and vulnerability level to climate change are prominent. The term 'smallholder' refers to the farmers with limited resources compared to other groups of farmers in the sector [58]. Smallholder farmers can cultivate as little as one hectare or as much as ten hectares or more, depending on population density and agro-ecological zones; often, no sharp distinction between smallholders and other larger farms is necessary.

Smallholders represent the largest number of farm holdings in Sub-Saharan African countries, however, there has been a proposed size limit to smallholders and family farms in certain regions or contexts. For example, Refs. [59-61] stated that the most common measure of a smallholder farm in Asia and the Pacific is one or two hectares or less of cropland. This is consistent with observations in SSA. The smallholder farmers are usually faced with many challenges, including access to limited funds for agricultural activities, low storage facilities, diseases and pests, and postharvest losses. The production and productivity from these farmers are low and may not be able to meet the growing need for food and fiber. This suggests that SSA will need to produce more to be able to feed its population. Moreover, an increase in population has been seen as a threat, as it puts pressure on limited 
natural resources, and increases the $\mathrm{CO}_{2}$ level in the atmosphere through farm activities, various logistics, and the industrial processing of agricultural commodities.

\subsection{Current Knowledge on the State of CSA Farmer Household Adoption in SSA}

Africa is most vulnerable to the effects of climate change, which is partly due to social, economic, and environmental factors. Climate change is rapidly interacting with non-climate drivers, and this amplifies the vulnerability of agricultural systems, mainly in the SSA region, as confirmed by FARA in 2015 [52]. The evidence of climate change has called for more knowledge in developing tools, technologies, and methods to deal with this global evil of our time, which has left SSA most vulnerable. Although there are CSA practices that have been adopted and used by farming households, these still have limited knowledge of the concept of CSA and its practices [62].

In recent years, the use of radios, televisions, and other communication tools to communicate weather variations, when to expect rain, and other factors relating to rainfall, have led to the easy adoption of some of these CSA technologies by farmers, both directly and indirectly. However, a case study conducted in 2016 in West Africa, as presented in Table 2, showed that the majority $(85.0 \%)$ of farmers rely on their personal experience to predict weather events, $75.3 \%$ depend on radio/television to access weather information, while $19.6 \%$ used a mobile phone to access weather information. Farmer-to-farmer knowledge sharing was recorded at $87.2 \%$.

Table 2. CSA practices adopted by farmers in West Africa.

\begin{tabular}{|c|c|}
\hline Practices & $\begin{array}{c}\text { Responses (\%) } \\
\text { Yes }\end{array}$ \\
\hline \multicolumn{2}{|l|}{ Weather smart } \\
\hline Use personal experience to predict weather events & 85.0 \\
\hline Usage information from radio/T.V for weather events & 75.3 \\
\hline Received training/education from an extension worker/agent on weather & 54.4 \\
\hline Use a mobile phone to access weather information & 19.6 \\
\hline Access to weather information on the internet & 11.8 \\
\hline \multicolumn{2}{|l|}{ Water smart } \\
\hline Plant early during the rainy season to make use of rainwater & 76.8 \\
\hline Plant cover crops to maintain soil moisture & 43.4 \\
\hline Harvest and store rainwater for future use in watering crops and feeding animals & 12.5 \\
\hline \multicolumn{2}{|l|}{ Carbon and nitrogen smart } \\
\hline Use organic manuring & 94.7 \\
\hline Practice mixed cropping & 94.7 \\
\hline Use trees as farm boundaries (afforestation) & 81.6 \\
\hline Practice crop rotation & 72.8 \\
\hline Plant legumes among crops & 82.5 \\
\hline Estimate the amount of fertilizer/manure needed at a time (precision fertilization) & 53.7 \\
\hline Use specific fertilizer/manure based on the type of soil (site-specific nutrients application) & 30.0 \\
\hline \multicolumn{2}{|l|}{ Energy smart } \\
\hline Compost residue after harvesting & 70.6 \\
\hline Convert residue into bioenergy & 14.0 \\
\hline Use solar equipment in farming & 10.9 \\
\hline \multicolumn{2}{|l|}{ Knowledge smart } \\
\hline Farmer-to-farmer knowledge sharing & 87.2 \\
\hline Belonging to a farmer association & 86.9 \\
\hline Store seeds for next season/emergency (seed banking) & 84.4 \\
\hline Get access to market information on prices of outputs and input & 40.0 \\
\hline
\end{tabular}

Source: Adapted from Samuel W. et al., 2019 [63].

A study report from [31] showed that between $25 \%$ and $34 \%$ of households across four localities in Tanzania had used at least one of the CSA technologies listed in Figure 6 on their farms during the growing season. However, they noticed that adoption rates varied 
by practices, therefore affirming the fact that CSA is location-, area-, and site-specific [64,65]. The application of chemical fertilizers was used by $34 \%$ of farmers across all regions of the study, with the highest adoption rates in Iringa (48.4\%). Livestock diversity and irrigation were the least commonly used practices at $26 \%$ each across all the regions of their study, although $46.7 \%$ of households reported irrigating their farms in Zanzibar. The highest livestock diversity recorded was in Iringa (41.9\%) and the lowest in Zanzibar with 9.7\%. Overall, $25.1 \%$ of the households had a diverse crop production.

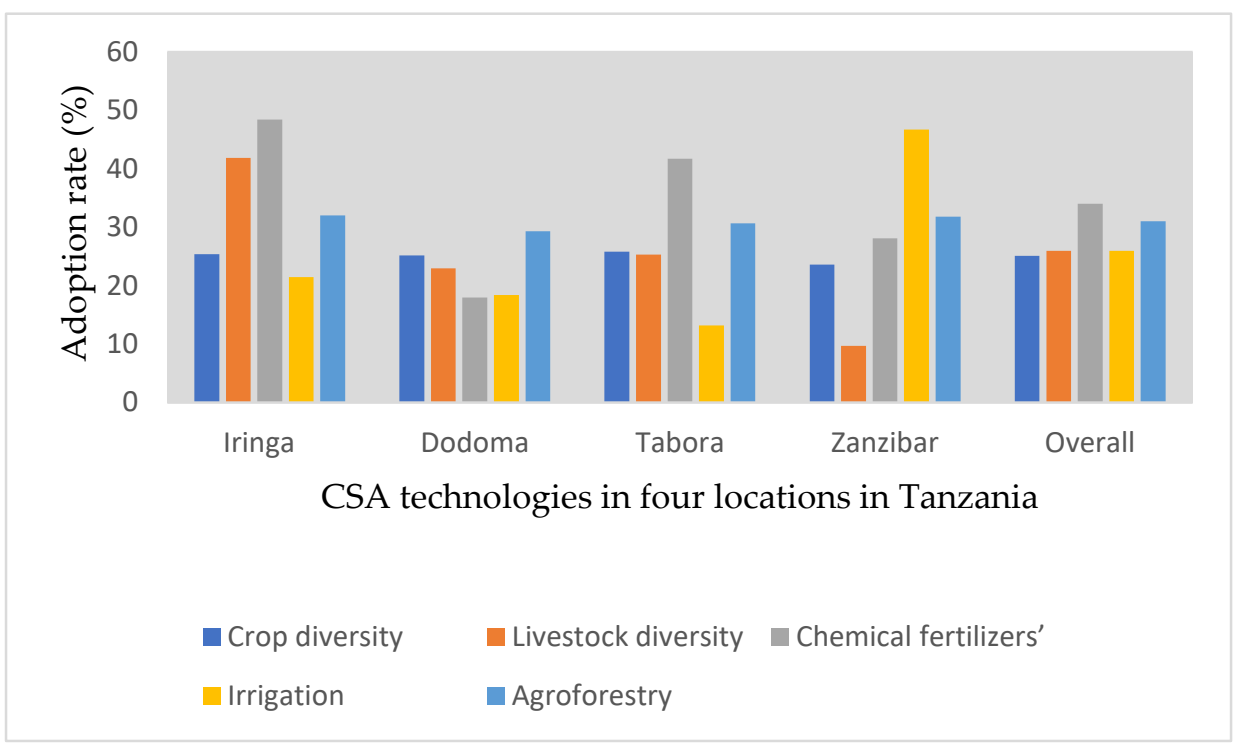

Figure 6. Adoption levels of CSA technologies in four (4) locations in Tanzania and the overall rate (\%). Source: [31].

Iringa is an urban city in East Africa with a population of about 151,000 people. It has a fairly dry, subtropical highland climate bordering on a tropical savanna climate, and it has a wet season from December to April. Zanzibar has a rainfall regime split into two main seasons, a primary maximum in March, April, and May in association with the southwest monsoon, and a secondary maximum in November and December [66], resulting in farming being the major activity in this area. Dodoma possesses a semi-arid climate with warm to hot temperatures throughout the year. While average highs are somewhat consistent throughout the year, average lows dip to $13^{\circ} \mathrm{C}\left(55.4{ }^{\circ} \mathrm{F}\right)$ in July. Dodoma averages 610 millimeters or 24 inches of rainfall per year, the vast majority of which occurs during its wet season between December and April. The remainder of the year comprises the city's dry season. Similarly, Tabora and its people mainly rely on agricultural activities as either sustenance farmers or small-scale farmers. It has a tropical savanna climate with two seasons of approximately equal length. The wet season is from November to April and is followed by a dry season from May to October. The figure below gives a presentation of the rate of CSA adoption in the four locations in Tanzania.

Broadly, farmers encounter several issues concerning their farming activities, as shown in Table 3 and Figure 6. From the two studies above of both West and Eastern Africa, farmers face some challenges, from economic issues to social and site-specific issues. Farmers agreed they had access to sustainable agriculture technologies in both regions, with little or no training at all. Moreover, although there are available CSA technologies in SSA, their utilization is still low. This confirms the report of [67] that CSA use by smallholder farms presents an added opportunity to embark on rigorous promotional campaigns for effective CSA adoption, and that this could begin with the local media and through the agricultural extension agents. Capacity building at all levels of CSA discourse is also very crucial. 
Table 3. CSA farm-level issues.

\begin{tabular}{cc}
\hline Issues & Mean \\
\hline Economic & \\
Access to sustainable agriculture technologies & 4.64 \\
Experience of bush fires & 4.02 \\
Drought occurrence & 4.89 \\
Experience of weeds and pesticides & 4.02 \\
Knowledge of climate-smart agriculture & 4.93 \\
Government or private sector support & 3.48 \\
Access to extension services & 3.90 \\
Availability of CSA funds by government and farmer organizations & 4.25 \\
\hline
\end{tabular}

Based on a scale of $1=$ strongly disagree, $2=$ disagree, $3=$ moderately agree, $4=$ agree, and $5=$ strongly agree Source: adapted from Samuel W. et al., 2019.

Climate change has caused some regions within SSA to become drier and hotter, and this has led to bush fires. Several burnt areas were recorded in SSA, and it was recorded that Guinea was the most affected. Data from 2014 through 2016 indicated that a total land area of about $41,905.31$ to $59,037.09 \mathrm{~km}^{2}$ was subjected to bush fires [68]. This is very alarming, as Sub-Saharan Africa is predicted to become warmer and drier by the year 2050 [69]. Leveraging sustainable agricultural technologies is the way to support growth in the sector; as shown in the table below, this provides the needed hope to African agriculture, as more farming households [70,71] confirmed that sustainable agriculture practices are the way to ensure a food-secure continent.

Knowledge networks that are supporting farmers with information on technologies, input, and output, as well as linkages to financial sources, are growing in Africa. For instance, the FARA D-groups platform (https: / / faraafrica.community / fara-net (accessed on 30 June 2021) is a well-acclaimed information dissemination instrument among agricultural research and development experts in Africa. The Innovation Platform Agribusiness Portal (https: / /ipabp.org/ (accessed on 30 June 2021)) is focused on compiling and disseminating best practices and useful research findings to farmers in an easily understandable language [57]. There are several other "platforms", such as the FAO TECA (http:/ / www.fao.org/teca/en/ (accessed on 30 June 2021)), which enhance the exchange of new knowledge and innovations for practical uptake and further adoption. With the growing knowledge of CSA in SSA, it is time to effectively engage the farming household with the entire process of developing CSA technologies. This will foster good technology demand testing good adoption since the technologies will address the need of the end-users, the farmers.

\section{Conclusions}

This review indicated that the research results that were presented at the Biennial Climate-Smart Agricultural Stakeholders Conference, held on 1st and 2nd December 2020 responded to the three pillars of CSA, namely, food security, adaptation, and mitigation. Our study revealed that the factors that hinder the adoption rate of CSA technologies in Africa include, poor engagement of the private sector actors; poor policy coherence, inadequate technical capacity to generate and disseminate technologies, and poor access to finances.

The farming household in most SSA countries is oblivious of the CSA technologies because of improper marketing. Most of the production systems that support good CSA practices are not new, and therefore the smallholder farmers are not convinced of the novelty when they are introduced. However, there has been an invention of varieties that are early maturing, drought-tolerant, pest and disease resistant, and can thrive under unfavorable weather conditions. It is imperative that the agricultural research and development actors in Africa need to properly define a technology or production practice as a CSA-compliant technology when will it qualify as such. This characterization is vital to ensure the proper packaging of different pieces of knowledge, technologies, and inventions 
that are disseminated under the label of CSA. The South-South and North-South-South partnerships could be explored for this knowledge and technology exchange, among countries as well as in capacity development.

Within Africa, there is the need for more effective collaboration between researchers, extensions, policymakers, and other non-state actors, in promoting the use of CSA-compliant technologies and production systems. This has received modest attention in the past through the development of the Agricultural Innovation Systems (AIS) as the mode of implementing agricultural research for measurable impacts. However, the AIS is still too much in its infancy to orchestrate the desired broad-based paradigm change.

SDG one and two (poverty eradication and zero hunger) stands the risk of not being achieved by the year 2030 if a drastic effort is not channeled to widely encourage access to sustainable technology and use in Africa agriculture.

Our study further showed that the demographic shift in Africa countries especially the recent upsurge in youth population and its different social implications, such as unemployment, rural-urban migration, increase in antisocial activities, violent behaviors, terrorism, etc. have an indirect but noticeable implication on climate change and the need for CSA. Other demographic changes, such as the increase in the proportion of individuals in the middle class has resulted in increasing demand for industrially processed food and more carbon emission.

As a recommendation, we propose good capacity building and youth empowerment to champion CSA technology adoption and utilization in the continent. It is further recommended that farmers are capacitated to change their orientation about the effect of climate change and the best practice to adopt in compliance with the three pillars of CSA.

Author Contributions: Conceptualization, P.S.; methodology, R.K., P.S. and O.A.F.; validation, R.K., P.S. and O.A.F.; formal analysis, R.K., P.S. and O.A.F.; investigation, R.K., P.S. and O.A.F.; data curation, R.K.; writing - original draft preparation, P.S. and O.A.F.; writing-review and editing, R.K.; visualization, P.S.; supervision, O.A.F. All authors have read and agreed to the published version of the manuscript.

Funding: This research received external funding from the European Union as part of the CAADPXP4 funded under the EU DeSIRA Programme.

Institutional Review Board Statement: Not applicable.

Informed Consent Statement: Not applicable.

Data Availability Statement: Not applicable.

Acknowledgments: We are thankful to the EC and IFAD for proving funds in support of CAADXP4 through which we were able to hold the Biennial Climate-Smart Stakeholders Conference-leading. We would like to thank all of the authors who presented papers during the conference and lastly, we acknowledge the SROs for their partnership and support in Africa's agricultural development.

Conflicts of Interest: The authors declare no conflict of interest.

\section{References}

1. Bolin, B. A history of the Science and Politics of Climate Change: The Role of the Intergovernmental Panel on Climate Change; Cambridge University Press: Cambridge, UK, 2007.

2. USAID. Climate Change Information Fact Sheet EGYPT. USAID Fact Sheet Report. 2015. Available online: https://www. climatelinks.org/sites/default/files/asset/document/Egypt\%20Climate\%20Info\%20Fact\%20Sheet_FINAL.pdf (accessed on 25 September 2021).

3. Connor, P. International Migration from Sub-Saharan Africa has Grown Dramatically Since 2010; Sub-Saharan Migration to the United States also Growing; Pew Research Center: Washington, DC, USA, 2018; Available online: https://www.pewresearch.org/ fact-tank/2018/02/28/international-migration-from-sub-saharan-africa-has-grown-dramatically-since-2010/ (accessed on 25 September 2021).

4. Fraval, S.; Hammond, J.; Bogard, J.R.; Ng'endo, M.; van Etten, J.; Herrero, M.; Oosting, S.J.; de Boer, I.J.; Lannerstad, M.; Teufel, N.; et al. Food access deficiencies in sub-Saharan Africa: Prevalence and implications for agricultural interventions. Front. Sustain. Food Syst. 2019, 3, 104. [CrossRef] 
5. FAO. Climate Change and Food Security: Risk and Responses. 2015. Available online: www.fao.org/publications (accessed on 10 May 2021)

6. Yamba, S.; Appiah, D.O.; Siaw, L.P. Smallholder farmers' perceptions and adaptive response to climate variability and climate change in southern rural Ghana. Cogent Soc. Sci. 2019, 5, 1646626. [CrossRef]

7. Available online: www.acetforafrica.org (accessed on 10 May 2021).

8. Partey, S.T.; Zougmoré, R.B.; Ouédraogo, M.; Campbell, B.M. Developing climate-smart agriculture to face climate variability in West Africa: Challenges and lessons learnt. J. Clean. Prod. 2018, 187, 285-295. [CrossRef]

9. FAO. Food Security and Agricultural Mitigation in Developing Countries: Options for Capturing Synergies FAO Rome. 2009. Available online: http:/ / www.fao.org/docrep/012/i1318e/i1318e00.pdf (accessed on 23 May 2021).

10. FAO. Climate-Smart Agriculture: Climate Change; Climate-Smart Agriculture I Food and Agriculture Organization of the United Nations: Rome, Italy, 2010.

11. Sub-Saharan-Africa. World Regional Geography. Available online: https:/ / andmcintyre.weebly.com (accessed on 7 June 2021).

12. Nelson, S.; Huyer, S. A Gender-Responsive Approach to Climate-Smart Agriculture: Evidence and Guidance for Practitioners; 2016; Available online: https://www.fao.org/3/be879e/be879e.pdf (accessed on 25 September 2021).

13. Snyder, H. Literature review as a research methodology: An overview and guidelines. J. Bus. Res. 2019, 104, 333-339. [CrossRef]

14. Halcomb, E.; Hickman, L. Mixed methods research. Nursing Standard: Promoting excellence in nursing care. Univ. Wollongong 2015, 29, 41-47.

15. Paul, J.; Criado, A.R. The art of writing literature review: What do we know and what do we need to know? Int. Bus. Rev. 2020, 29, 101717. [CrossRef]

16. Faurès, J.M.; Santini, G. Water and the Rural Poor: Interventions for Improving Livelihoods in Sub-Saharan Africa. 2008. Available online: https:/ / reliefweb.int/report/world/water-and-rural-poor-interventions-improving-livelihoods-sub-saharan-africa (accessed on 25 September 2021).

17. Available online: https://www.africa.undp.org/content/rba/en/home/regioninfo.html (accessed on 11 April 2021).

18. FAO; IIASA. Global Agro-Ecological Zones (GAEZ); 2000. Available online: https://iiasa.ac.at/web/home/research/ researchPrograms/water/GAEZ_v4.html (accessed on 25 September 2021).

19. Wilson, J.W.; Primack, R.B. Conservation Biology in Sub-Saharan Africa; Open Book Publishers: Cambridge, UK, 2019 ; pp. 23-60. Available online: https:/ /www.openbookpublishers.com/product/1013 (accessed on 25 September 2021).

20. Girvetz, E.; Ramirez-Villegas, J.; Claessens, L.; Lamanna, C.; Navarro-Racines, C.; Nowak, A.; Rosenstock, T.S. Future Climate Projections in Africa: Where Are We Headed? In The Climate-Smart Agriculture Papers; Springer: Cham, Switzerland, 2019; pp. 15-27.

21. Zougmoré, R.B.; Läderach, P.; Campbell, B.M. Transforming Food Systems in Africa under Climate Change Pressure: Role of Climate-Smart Agriculture. Sustainability 2021, 13, 4305. [CrossRef]

22. Osumba, J.J.L.; Recha, J.W.; Oroma, G.W. Transforming Agricultural Extension Service Delivery through Innovative Bottom-Up Climate-Resilient Agribusiness Farmer Field Schools. Sustainability 2021, 13, 3938. [CrossRef]

23. Obi, A.; Maya, O. Innovative Climate-Smart Agriculture (CSA) Practices in the Smallholder Farming System of South Africa. Sustainability 2021, 13, 6848. [CrossRef]

24. Beattie, S.; Sallu, S.M. How Does Nutrition Feature in Climate-Smart Agricultural Policy in Southern Africa? A Systematic Policy Review. Sustainability 2021, 13, 2785. [CrossRef]

25. Geda, S.A.; Kühl, R. Exploring Smallholder Farmers' Preferences for Climate-Smart Seed Innovations: Empirical Evidence from Southern Ethiopia. Sustainability 2021, 13, 2786. [CrossRef]

26. Zeleke, T.; Beyene, F.; Deressa, T.; Yousuf, J.; Kebede, T. Vulnerability of Smallholder Farmers to Climate change-induced Shocks in East Hararghe Zone, Ethiopia. Sustainability 2021, 13, 2162. [CrossRef]

27. Ofoegbu, C.; Chirwa, P.W.; Francis, J.; Babalola, F.D. Assessing local-level forest use and management capacity as a climate-change adaptation strategy in Vhembe district of South Africa. Clim. Dev. 2019, 11, 501-512. [CrossRef]

28. Climate Change and Agriculture A Perfect Storm in Farm Country. Available online: https://www.ucsusa.org/resources/ climate-change-and-agriculture (accessed on 11 April 2021).

29. Upscaling Climate-Smart Agriculture (CSA) Adoption in Africa. Available online: http://www.fao.org/fileadmin/user_upload/ gacsa/docs/POLICY_BRIEF_-_CSA.pdf (accessed on 18 August 2021).

30. Onoja, A.O.; Abraha, A.Z.; Girma, A.; Achike, A.I. Climate-smart agricultural practices (CSA) adoption by crop farmers in semi-arid regions of the west and east Africa: Evidence from Nigeria and Ethiopia. In Climate Change-Resilient Agriculture and Agroforestry; Springer: Cham, Switzerland, 2019; pp. 89-113.

31. Kurgat, B.K.; Lamanna, C.; Kimaro, A.; Namoi, N.; Manda, L.; Rosenstock, T.S. Adoption of climate-smart agriculture technologies in Tanzania. Front. Sustain. Food Syst. 2020, 4, 55. [CrossRef]

32. Bell, P.; Namoi, N.; Lamanna, C.; Corner-Dolloff, C.; Girvetz, E.H.; Thierfelder, C.; Rosenstock, T.S. A Practical Guide to ClimateSmart Agriculture Technologies in Africa; CCAFS Working Paper no. 224.; CGIAR Research Program on Climate Change, Agriculture and Food Security (CCAFS): Wageningen, The Netherlands, 2018.

33. Barasa, P.M.; Botai, C.M.; Botai, J.O.; Mabhaudhi, T. A Review of Climate-Smart Agriculture Research and Applications in Africa. Agronomy 2021, 11, 1255. [CrossRef] 
34. Field, C.B.; Barros, V.R. (Eds.) Climate Change 2014-Impacts, Adaptation and Vulnerability: Regional Aspects; Cambridge University Press: Cambridge, UK, 2014; Available online: https://www.ipcc.ch/report/ar5/wg2/ (accessed on 25 September 2021).

35. How Climate Change is Making Record-Breaking Floods the New Normal. Available online: https://www.unep.org/news-andstories/story/how-climate-change-making-record-breaking-floods-new-normal (accessed on 9 July 2021).

36. Serdeczny, O.; Adams, S.; Baarsch, F.; Coumou, D.; Robinson, A.; Hare, W.; Schaeffer, M.; Perrette, M.; Reinhardt, J. Climate change impacts in Sub-Saharan Africa: From physical changes to their social repercussions. Reg. Environ. Chang. 2017, 17, 1585-1600. [CrossRef]

37. Asante, F.A.; Amuakwa-Mensah, F. Climate Change and Variability in Ghana: Stocktaking. Climate 2015, 3, 78-99. [CrossRef]

38. Morales-Muñoz, H.; Jha, S.; Bonatti, M.; Alff, H.; Kurtenbach, S.; Sieber, S. Exploring Connections-Environmental Change, Food Security and Violence as Drivers of Migration-A Critical Review of Research. Sustainability 2020, 12, 5702. [CrossRef]

39. World Bank. Ending Poverty and Hunger by 2030: An Agenda for the Global Food System, 2nd ed.; World Bank Group: Washington, DC, USA, 2015.

40. Rippke, U.; Ramirez-Villegas, J.; Jarvis, A.; Vermeulen, S.J.; Parker, L.; Mer, F.; Diekkrüger, B.; Challinor, A.J.; Howden, M. Timescales of transformational climate change adaptation in sub-Saharan African agriculture. Nat. Clim. Chang. 2016, 6, 605-609. [CrossRef]

41. Müller, C.; Waha, K.; Bondeau, A.; Heinke, J. Hotspots of climate change impacts in sub-Saharan Africa and implications for adaptation and development. Glob. Chang. Biol. 2014, 20, 2505-2517. [CrossRef]

42. Shi, W.; Tao, F. Vulnerability of African maize yield to climate change and variability during 1961-2010. Food Secure. 2014, 6, 471-481. [CrossRef]

43. Rurinda, J.; Van Wijk, M.T.; Mapfumo, P.; Descheemaeker, K.; Supit, I.; Giller, K.E. Climate change and maize yield in southern Africa: What can farm management do? Glob. Chang. Biol. 2015, 21, 4588-4601. [CrossRef]

44. Ahmed, S.; Griffin, T.S.; Kraner, D.; Schaffner, M.K.; Sharma, D.; Hazel, M.; Leitch, A.R.; Orians, C.M.; Han, W.; Stepp, J.R.; et al. Environmental Factors Variably Impact Tea Secondary Metabolites in the Context of Climate Change. Front. Plant Sci. 2019, 10, 939. [CrossRef]

45. Vogel, C.; Steynor, A.; Manyuchi, A. Climate services in Africa: Re-imagining an inclusive, robust and sustainable service. Clim. Serv. 2019, 15, 100107. [CrossRef]

46. Batley, J.; Edwards, D. The application of genomics and bioinformatics to accelerate crop improvement in a changing climate. Curr. Opin. Plant Biol. 2016, 30, 78-81. [CrossRef] [PubMed]

47. Harfouche, A.L.; Jacobson, D.A.; Kainer, D.; Romero, J.C.; Harfouche, A.H.; Mugnozza, G.S.; Moshelion, M.; Tuskan, G.A.; Keurentjes, J.J.; Altman, A. Accelerating climate resilient plant breeding by applying next-generation artificial intelligence. Trends Biotechnol. 2019, 37, 1217-1235. [CrossRef] [PubMed]

48. Mortimer, J.C. Plant synthetic biology could drive a revolution in biofuels and medicine. Exp. Biol. Med. 2019, $244,323-331$. [CrossRef]

49. SDG Knowledge Hub, CIAT Strategy Responds to Climate Change, Land Degradation. Available online: http://sdg.iisd.org/ news/ ciat-strategy-responds-to-climate-change-land-degradation/ (accessed on 12 August 2021).

50. Khatri-Chhetri, A.; Aggarwal, P.K.; Joshi, P.K.; Vyas, S. Farmers' prioritization of climate-smart agriculture (CSA) technologies. Agric. Syst. 2017, 151, 184-191. [CrossRef]

51. Ruddle, K.; Zhong, G. Integrated Agriculture-Aquaculture in South China: The Dike-Pond System of the Zhujiang Delta; CUP Archive: Cambridge, UK, 1988; Available online: https:/ / www.researchgate.net/publication/258212339_Integrated_AgricultureAquaculture_in_South_China_The_Dike-Pond_System_of_the_Zhujiang_Delta (accessed on 25 September 2021).

52. Kipkoech, A.K.; Tambi, E.N.; Bangali, S.; FARA. State of Knowledge on CSA in Africa, Case Studies from Ethiopia, Kenya and Uganda; Forum for Agricultural Research in Africa: Accra, Ghana, 2015; Available online: https://www.worldcat.org/title/state-ofknowledge-on-csa-in-africa-case-studies-from-ethiopia-kenya-and-uganda/oclc/968333705 (accessed on 25 September 2021).

53. Chinedum, N.; Tambi, E.N.; Bangali, S. State of Knowledge on CSA in Africa: Case Studies from Burkina Faso, Senegal and Sierra Leone; Forum for Agricultural Research in Africa: Accra, Ghana, 2015.

54. Urbanization in Sub-Saharan Africa. Available online: statista.com (accessed on 17 July 2021).

55. Fleshman, M. Saving Africa's forests, the 'lungs of the world'. Afr. Renew. 2008, 21, 5-7. [CrossRef]

56. Pigford, A.A.E.; Hickey, G.M.; Klerkx, L. Beyond agricultural innovation systems? Exploring an agricultural innovation ecosystems approach for niche design and development in sustainability transitions. Agric. Syst. 2018, 164, 116-121. [CrossRef]

57. Rudel, T.K. The national determinants of deforestation in sub-Saharan Africa. Philos. Trans. R. Soc. B Biol. Sci. 2013, 368, 20120405. [CrossRef]

58. Dixon-Woods, M.; Agarwal, S.; Young, B.; Jones, D.; Sutton, A. Integrative Approaches to Qualitative and Quantitative Evidence; Health Development Agency: London, UK, 2004; p. 181.

59. Thapa, R.B.; Murayama, Y. Drivers of urban growth in the Kathmandu valley, Nepal: Examining the efficacy of the analytic hierarchy process. Appl. Geogr. 2010, 30, 70-83. [CrossRef]

60. Hasegawa, T.; Fujimori, S.; Havlík, P.; Valin, H.; Bodirsky, B.L.; Doelman, J.C.; Fellmann, T.; Kyle, P.; Koopman, J.F.; Lotze-Campen, H.; et al. Risk of increased food insecurity under stringent global climate change mitigation policy. Nat. Clim. Chang. 2018, 8, 699-703. [CrossRef]

61. Countries and Territories. Available online: http:/ /www.fao.org/faostat/en/ (accessed on 5 May 2021). 
62. Abegunde, V.O.; Sibanda, M.; Obi, A. The dynamics of climate change adaptation in Sub-Saharan Africa: A review of climatesmart agriculture among small-scale farmers. Climate 2019, 7, 132. [CrossRef]

63. Anuga, S.W.; Gordon, C.; Boon, E.; Surugu, J.M.I. Determinants of Climate-Smart Agriculture (CSA) Adoption among Smallholder Food Crop Farmers in the Techiman Municipality, Ghana. Ghana J. Geogr. 2019, 11, 124-139.

64. Food and Agriculture Organization (FAO) of United Nations. Climate-Smart Agriculture Sourcebook; United Nations FAO: Rome, Italy, 2013; Available online: https:/ / www.fao.org/3/i3325e/i3325e.pdf (accessed on 25 September 2021).

65. Ministry of Food and Agriculture-MOFA. National Climate-Smart Agriculture Action Plan (2016-2020); Ministry of Food and Agriculture: Accra, Ghana, 2015.

66. Ingham, K.; Mascarenhas, A.C.; Chiteji, F.M.; Bryceson, D.F. Tanzania. Encyclopedia Britannica, 19 March 2021. Available online: https://www.britannica.com/place/Tanzania (accessed on 25 September 2021).

67. Totin, E.; Roncoli, C.; Traoré, P.S.; Somda, J.; Zougmoré, R. How does institutional embeddedness shape innovation platforms? A diagnostic study of three districts in the Upper West Region of Ghana. NJAS-Wagening. J. Life Sci. 2018, 84, 27-40. [CrossRef]

68. Yamba, S.; Appiah, D.O.; Pokuaa-Siaw, L.; Asante, F. Smallholder Farmers' Livelihood Security Options Amidst Climate Variability and Change in Rural Ghana. Scientifica 2017, 2017, 1868290.

69. Schellnhuber, H.J.; Hans, J.; Katja, F.; Pavel, K. The Elephant, the Blind, and the Intersectoral Intercomparison of Climate Impacts. Proc. Natl. Acad. Sci. USA 2014, 111, 3225-3227. Available online: https:/ /www.pnas.org/content/111/9/3225 (accessed on 25 September 2021).

70. Adenle, A.A.; Wedig, K.; Azadi, H. Sustainable agriculture and food security in Africa: The role of innovative technologies and international organizations. Technol. Soc. 2019, 58, 101143. [CrossRef]

71. World Population Prospects-Population Division. United Nations Department of Economic and Social Affairs, Population Division. Available online: population.un.org (accessed on 25 September 2021). 